\title{
Native American Integration in 19th Century Anglo-American Society: An Archaeological Perspective from Northeastern Texas
}

Frank Winchell

Unknown

David H. Jurney

Follow this and additional works at: https://scholarworks.sfasu.edu/ita

Part of the American Material Culture Commons, Archaeological Anthropology Commons, Environmental Studies Commons, Other American Studies Commons, Other Arts and Humanities Commons, Other History of Art, Architecture, and Archaeology Commons, and the United States History Commons

Tell us how this article helped you.

This Article is brought to you for free and open access by the Center for Regional Heritage Research at SFA ScholarWorks. It has been accepted for inclusion in Index of Texas Archaeology: Open Access Gray Literature from the Lone Star State by an authorized editor of SFA ScholarWorks. For more information, please contact cdsscholarworks@sfasu.edu. 
Native American Integration in 19th Century Anglo-American Society: An Archaeological Perspective from Northeastern Texas

\section{Creative Commons License}

(c) (1) (8)

This work is licensed under a Creative Commons Attribution-NonCommercial 4.0 International License 


\title{
Native American Integration in 19th Century Anglo-American Society: An Archaeological Perspective from Northeastern Texas
}

\author{
Frank Winchell and David H. Jurney
}

This paper will examine the phenomenon of Native American-Anglo-American integration on the frontier of Northeastern Texas during the 19th century. First, a brief overview of the historic setting will be presented on where and how this integration took place and who were the primary players. Second, we discuss the material cultural manifestations of this interaction, and what problems it presents for interpreting the archaeological record. Finally, we conclude that what have been previously described and defined as typical 19th century Anglo-American frontier homesteads of Northeastern Texas warrant a different interpretive perspective, and in fact, many of these "typical" first wave pioneer Anglo-American homesteads may actually represent mestizo occupations.

\section{Background}

Other than the ephemeral traces of the colonial Spanish and French, the period of historic settlement in Northeastern Texas began with the simultaneous arrival of immigrant Native Americans and Anglo-Americans--the majority of whom emigrated originally from the southeastern United States. The culture area of Northeastern Texas is defined by the lands which were traditionally inhabited by tribes affiliated with the Kadohadacho (comprising the Kadohadacho, Nasoni, Upper Natchitoches, and Nadzoos [Nanatsoho]) who were located within the Red River Valley (see Hidalgo 1716; Newcomb 1974:25).

The first legitimate immigrant group to settle the lands south of the Red River in Northeastern Texas were the Cherokee (invited by the Caddo and sanctioned by the Spanish authorities) who entered the former Kadohadacho territories in 1819 and briefly established a camp in the area called Three Forks of the Trinity close to what is now Dallas, Texas (Starr 1917; Clarke 1971:14). Before long, they were driven off by an unknown group of Indians (probably the Osage) and were compelled to settle near Nacogdoches in East Texas where they established a permanent settlement north of the town between the Sabine (to the north), Neches (to the west), Angelina (to the east), and the Old San Antonio Road (to the south) (Starr 1917:179). The Cherokee lived there for some twenty years, adjacent to Hasinai Caddo tribes and the Alabama-Koasati Creek, until they were forced out by the Anglo-Americans in 1839 (Clarke 1971:94-111).

Hot on the trails of the migrant Cherokees, and other immigrant Indians from the southeastern United States, were the Anglo-Americans who quickly filtered into Northeastern Texas as early as 1817 and settled along the Red River in both present-day 
Oklahoma and Texas (Strickland 1937; Jordan 1981:86-87). These early Anglo-American settlements in Northeastern Texas were known as the "Red River Settlements" and were considered by the Spanish government as illegal encroachments into sovereign territory. Conversely, by 1830 many Anglo-Americans living on the north side of the Red River were forced by the United States government to move south of the river on the basis that they were illegally occupying established Choctaw lands in Indian Territory (Jordan 1981:87).

On the north side of the Red River lived the five so-called "Civilized Tribes", who were considered civilized because they were fully assimilated homesteaders of the American frontier who were governed by native bicameral legislatures, lived in log-framed houses, and practiced agriculture. The five civilized tribes (who had settled parts of Indian Territory by the first quarter of the 19th century) consisted of the Cherokee, Choctaw, Chickasaw, Creek, and Seminole (Doran 1976:47).

In the initial years of joint settlement by both the immigrant Native Americans and Anglo-Americans in Northeastern Texas, it is noteworthy to examine the state of affairs between these various groups in a letter written by the Indian agent John Jamison to the Secretary of War from Natchitoches, Louisiana on May 10, 1817. Essentially, Jamison wrote about a trip he took up the Red River from Natchitoches where at Pecan Point (situated on the Texas side in present-day Red River county) he encountered " a number of [Anglo-American] families squatting on Caddo land" (Carter 1951:302-303). On his retum trip down river from Pecan Point, he remarks that there were also villages of Cherokee, Delaware, and Koasati on the Red River. The contingent of Cherokees encountered by Jamison were probably the ones who had entered Northeastern Texas and camped at the Three Forks of the Trinity. Furthermore, Jamison mentions that the Caddo, Choctaw, Cherokee, and Koasati were all at war with the Osage. Less than a year later on January 13,1818 , the explorer Thomas A. Long stated that the Caddo as a group had "dwindled to a mere handful" and lived "on the south side of the Red River" (Carter 1953:4-5).

During the initial period of settlement in Northeastern Texas, somewhere between 1817 and 1860, both the Native Americans and the Anglo-Americans shared a very similar economic base revolving around the herding of cattle (Doran 1976; Jordan 1981:86-102). As pointed out below, the archaeological vestiges of the particular economic pattern would likely fail to show the differences between a Native American or Anglo-American occupation, except for occasional subtle clues. Furthermore, it is possible that some (if not many) of these initial settlements shared both Anglo-American and Native American elements. 


\section{Native American and Anglo-American Cattle Herders}

Lands north of the Pineywoods in East Texas (which prior to 1839 were jointly inhabited by the Cherokee, the Alabama-Koasati Creek, and the Anglo-Americans) were dominated by a mosaic of riparian hardwood forests and fertile tall grass prairies that were conducive to the grazing of cattle (Jordan 1981:83-87). These lands along the Red, Sulphur, and Upper Trinity River basins attracted both immigrant Native Americans and southeastern Anglo-American cattle herders who had developed a highly efficient practice of frontier animal husbandry based on the open range herding of semi-feral cattle and pigs (Jordan 1969, 1981; Doran 1976:51-53). This economic base was established in the late 17 th and early 18 th century in the southeastern United States and was characterized by (quoted from Jordan 1969:71):

1) "large numbers of cattle,

2) open-range herding, branding, and round ups,

3) overland driving to market,

4) unimproved breeds of cattle,

5) extensive land use by cattle herders,

6) employment of labor beyond the family unit,

7) herd supervision from horseback, [and]

8) generally secondary importance of cropping".

By the 1830 s, this economic base was fully transplanted by Native Americans living in Indian Territory. Prior to the Civil War they were exporting their herds to markets all over the Midwest (such as Indiana, Missouri, and Illinois) and even as far as California (Doran 1976:52-54). Of the five civilized tribes, the Choctaw and Chickasaw were herding cattle on the Oklahoma side of the Red River at this time (Doran 1976:52). It is of no small coincidence that both Anglo-Americans and Native Americans were both settling the same lands in Southeastern Oklahoma and Texas. This can be attributed to the fact that they were inexorably involved within the same socio-economic tradition, and were part of the same frontier cultural process. It is of no small consequence that the early history of Northeastem Texas just prior to, and after the Texas War for Independence, revolved around a struggle for land between two different ethnic groups of equal economic status.

\section{The Mestizo Phenomenon}

The clear cultural dichotomy between Native American and Anglo-American cattle herding societies is clouded by the fact that there was considerable physical integration between the two social groups, and for lack of a better word, this interaction can be termed as "the mestizo phenomenon". The mestizo phenomenon within cattle herding societies in 
both Northeastern Texas and Southeastern Oklahoma was unquestionably high along the frontier zone on either side of the Red River (see Jordan 1981:100; Doran 1976:56-57); this is not surprising given the close proximity of both Native Americans and Anglo-Americans that were part of the same economic system. It is significant to note, however, that mestizos in general were widely accepted within Native American societies living on the frontier (see Starr 1917), while on the other hand, it was less acceptable to be recognized as a mestizo in 19th century Anglo-American society; this latter fact has probably masked the true extent of Anglo-American miscegenation in the frontier regions.

A glimpse of this mestizo phenomenon in Northeastern Texas can be noted in one of the life histories of an Anglo-American cattle herder by the name of Kendall Lewis. Lewis was originally a native of Maryland and had "migrated to Georgia" as a boy in 1790 (Jordan 1981:101). From Georgia, he fled "as an outlaw to the Creek Indian Nation in Alabama and became a Creek citizen and married a woman from that tribe" (Ibid.). Lewis then moved "to Oklahoma with his adopted people in 1828 but was not allowed to have title to the land there" (Jordan 1981:101). In 1835, "he moved across the Red River into [Northeastern] Texas and settled a land grant near Prairie Branch in what is now...Titus County, Texas". Once established in Texas, Lewis's family prospered, and his cattle herd increased from 75 to 320 head between the years 1838 to 1844 (Texas Tax lists for Red River County 1834-1844 from Jordan 1981:101).

Unfortunately, the degree of intermarriage between Native Americans and AngloAmericans is not very well documented in Northeastern Texas during the 19th century, nor is there any information on how the different cultures influenced one another. Nevertheless, archival information such as that cited above has proven to be quite insightful on the subject of integration between Native American and Anglo-American herders.

\section{The Archaeological Record}

The remainder of this paper will examine several archaeological sites in Northeastem Texas that appear to reflect the mestizo phenomenon resulting from the interaction of Native Americans and Anglo-Americans. The three examples given below will demonstrate the complexity of the archaeological record during this period of Native American-AngloAmerican integration.

\section{The Eldridge Bottoms Site (41FT89)}

The Eldridge Bottoms site is located in Freestone County approximately nine miles east of Lake Limestone. This site represents the remains of a 1850-1870 homestead located on a 
promontory overlooking a small east-running tributary of the Trinity River called Silver Creek (Jurney 1992).

For all intents and purposes, the material culture of this site is totally Anglo-American in content. The archival records, however, show otherwise. This particular 19th century homestead was inhabited by Eldridge and Eliza Bottoms and their six children (Jurney 1992). Eldridge Bottoms was a $3 / 4$ Native American of Choctaw and Ouachatuba descent. His wife Eliza was a full-blooded Anglo-American. Sometime prior to 1840, Bottoms left his ancestral lands and traveled west across the Mississippi River into Indian Territory. Bottoms probably left Indian Territory and crossed into Northeastem Texas sometime between 1840 and 1850. It appears that he resided for a short time in Cherokee County (the former lands of the Texas Cherokee) and then moved to Freestone County during the 1850s. There, he married Eliza Self and had six children. Eldridge Bottoms died in 1868; there are over 30 descendants living today who claim ancestry to the Eldridge Bottoms family (Jumey 1992).

\section{The Robert Hanna Site (41DT126)}

The Robert Hanna site is located in Delta County, Texas along the South Sulphur River, about 100 miles north of the Eldridge Bottoms site. This site represents a 19th century homestead that was probably occupied by the first recorded landowners sometime between 1840 and 1893.

At first glance, this site also appears to represent a typical Anglo-American homestead. However, upon closer examination, this site has yielded some artifacts of peculiar character. In a pit-like feature on this site, four partial aboriginal earthenware pots were found in situ as part of what was first believed to be a disturbed prehistoric Caddoan burial. In association with these broken pots were the fragments of three partial historic artifacts consisting of a flow-blue transitional ironstone plate, a blue-green whiskey flask, and a polychrome transfer print transitional ironstone tea cup. The aboriginal pots displayed obvious signs of post-breakage firing, which could only have occurred when the broken pots were exposed to an open fire. In addition, practically all of the artifacts (both European and aboriginal) within this feature were large pieces, significantly larger than any of the artifacts outside the feature which seemed to represent typical historic sheet refuse. All of this evidence strongly suggested that the aboriginal pots were not: (1) associated with a burial, and (2) that the historic European artifacts were deposited in the pit-like feature (probably a trash pit) at roughly the same time. The historic artifacts found within the pit can be tightly bracketed between 1825 and 1850 with a terminus post quem being prior to 1855 . 
The aboriginal vessels in the feature (three of which were carinated) seemed to be no different from other Caddo pots recovered from prehistoric occupations in Northeastem Texas, except for one factor. One of the partial aboriginal pots had punctation marks unlike any known punctated decorations related to Caddo ceramics. Indeed, the punctated designs noted on the aboriginal vessel at the Robert Hanna site were produced by a pinpoint-like stylus, something akin to a metal pin. Furthermore, the pinpoint punctated design on this particular vessel is nothing like any other known Caddo decorative motif. Given these data, it may be speculated that the aboriginal vessels from the trash pit are not prehistoric in age but are possibly historic in age, perhaps also dating to the $1825-1850$ period.

Currently, there is very little information available about historic aboriginal potters from east of the Mississippi Valley who continued to produce traditional vessels during the early settlement period in both Texas and Oklahoma. Many of us are just beginning to realize that there are a whole host of historic Native American ceramics which we know little about and still do not always recognize them as such in the archaeological record. Therefore, it is possible that the mysterious pit-like feature at the Robert Hanna site may be associated with another example of an integrated Native American and Anglo-American homestead. To date, there is no archival data to support the contention that a Native American was residing at the Robert Hanna homestead. Nevertheless, it is plausible that someone at this particular homestead was still making traditional, historic aboriginal pottery.

\section{The Sinclair Cemetery (41DT105)}

The last site which we will briefly touch upon represents a small multi-family historic 19th century Anglo-American cemetery located in Delta County (not far from the Robert Hanna site) along the Old Jefferson to Bonham road. This site consists of 16 graves, most of which were 1850s-1880s burials with hexagonal wood coffins. Overall, these burials reveal the typical pre-railroad burial material culture and customs of Anglo-American inhumations. Nevertheless, the dentition from the biological remains suggests that some of the individuals buried at the Sinclair Cemetery were mestizo, that is of a "genetic admixture" between Anglo-American Europeans and Native Americans (Winchell and Rose 1990:13-10). Indeed, Mongoloid traits (suggestive of Native American genetic affiliation) such as shovel-shaped incisors, protostylids, maxillary Cusps 5, and mandibular Cusps 6 and 7 (Hanihara 1969) were present in the dentition of many individuals interred there (Winchell and Rose 1990:13-3).

At this particular cemetery, there were no artifacts of Native American origin, suggesting that the individuals were fully assimilated into a typical Anglo-American society existing on the frontier of Northeastern Texas. In the end, we are left with the perplexing 
question of whether we are dealing with anglicized Native Americans, or indianized AngloAmericans living along the frontier in Northeastern Texas. The overriding conclusion is that we are dealing with both in varying shades of gray.

\section{Conclusions}

To conclude, we believe that the 19th century frontier region of Northeastern Texas cannot be solely described as an Anglo-American phenomenon. The reality is that this particular region was inhabited by both immigrant Native Americans and Anglo-Americans who were interacting and participating as frontiersmen within the same economic system. Indeed, the three 19th century sites discussed above reveal this integrative process.

It should be pointed out that the identification of these particular kinds of sites in Northeastern Texas and elsewhere is not an easy task for archaeologists, and may suggest that we have underestimated the magnitude of this integrative process between Native Americans and Anglo-Americans. In Northeastem Texas, the three sites used as examples in this discussion actually represents the tail end of this process (ending shortly after the Civil War), further suggesting that many historic sites dating prior to the 1840 s may show even stronger characteristics of the integration between Native Americans and AngloAmericans.

\section{Acknowledgements}

This paper was presented by the senior author at the 1990 Texas Archeological Society meetings in Dallas. Many of the thoughts expressed in this paper originated from prior research by the junior author. Both authors would like to thank Randy Moir for his professional support during the research and writing phases of this paper.

\section{References Cited}

Carter, C. (editor)

1951 Louisiana-Missouri Territory, 1815-1821. The Territorial Papers of the United States, Volume XV. Government Printing Office, Washington, D.C.

1953 The Territory of Arkansas, 1825-1829. The Territorial Papers of the United States, Volume XIX. Government Printing Office, Washington, D.C.

Clarke, $M$.

1971 Chief Bowles and the Texas Cherokees. University of Oklahoma Press, Norman.

Doran, M.

1976 Antebellum Cattle Herding in the Indian Territory. Geographic Review 66:4858. 
Hanihara, $\mathrm{K}$.

1969 Mongoloid Dental Complex in the Permanent Dentition. Proceedings of the 8th International Congress of Anthropology and Ethnology, pp. 298-300. Tokyo and Kyoto.

Hidalgo, Fray Fransisco

1716 Fray Fransisco Hidalgo to the Viceroy, November 4, 1716. In "Descriptions of the Tejas or Asinai Indians, 1691-1722", edited and translated by Mattie Austin Hatcher. Southwestern Historical Quarterly XXXI:50-62.

Jordan, T.G.

1969 A Documentation of Diffusion from the Lower South. Economic Geography 45:63-87.

1981 Trails to Texas: Southern Roots of Western Cattle Ranching. University of Nebraska Press, Lincoln.

Jurney, D.H.

1992 Archaeological Survey, Historic Site Evaluations and Excavations at the Jewett Mine, Leon and Freestone Counties, Texas: 1989 Field Season. Archaeology Research Program, Southem Methodist University, Dallas.

Newcomb, W.W.

1974 North American Indians: an Anthropological Perspective. The University of Texas Press, Austin.

Starr, E.

1917 Early History of the Cherokees: Embracing Aboriginal Customs, Religion, Laws, Folk Lore, and Civilization. Privately published.

Strickland, R.

1937 Anglo-American Activities in Northeast Texas, 1803-1845.

Unpublished Ph.D. dissertation, University of Texas at Austin.

Winchell, F. and J.C. Rose

1990 Gone But Not Forgotten: Excavations at the Sinclair Cemetery

(41DT105). Draft Report submitted to U.S. Army Corps of Engineers, Fort

Worth District by Archaeology Research Program, Southern Methodist University, Dallas. 